\title{
FREI LUÍS DE SOUSA - UM CLÁSSICO ROMÂNTICO
}

Marcelo Corrêa Sandmann ${ }^{*}$

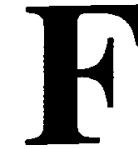

rei Luis de Sousa, de Almeida Garrett, tem sido considerado pela historiografia literária um dos principais textos dramáticos da literatura portuguesa. ${ }^{1}$ Finalizado em 1843, representado pela primeira vez em 4 de julho desse mesmo ano por um grupo de atores amadores, do qual fazia parte o próprio autor, e publicado em livro no ano seguinte, o texto baseia-se em episódios da vida de Manuel de Sousa Coutinho (c. 1555 - 1632), mais conhecido como Frei Luís de Sousa, nome adotado após o ingresso na ordem dos dominicanos em 1613 e com o qual ficaria conhecido como importante prosador do classicismo português.

* Universidade Federal do Paraná

1 Cf. a esse respeito o que dizem António Saraiva e Óscar Lopes, na sua consagrada História da literatura portuguesa, ao comentarem a obra dramática de Garrett: "Noutro plano muito superior se recorta o Frei Luls de Sousa (1844), obra solitária não apenas na literatura portuguesa. e no teatro romântico em geral, mas até no próprio teatro garrettiano." (p. 744) De modo ainda mais enfático exprime-se o verbete Frei Luís de Sousa, do Pequeno dicionário de literatura pornuguesa. organizado por Massaud Moisés: "Com muita razão o texto é considerado como o que de melhor o teatro português produziu depois de Gil Vicente." (p. 151) E ainda uma passagem da nota introdutória redigida por J. Tomaz Ferreira à edição do drama pela Europa-América vai frisar essa avaliação: "estamos sem dúvida perante uma obra-prima, quiçá a mais perfeita que a dramaturgia nacional já produziu". (p. 32) 
Este substrato histórico do texto de Garrett já de imediato poderia sugerir sua filiação a um gênero romântico por excelência, o do drama histórico, que ao lado do romance, histórico ou de atualidade, tinham conquistado a preferência do público da primeira metade do século XIX. Mas apesar da sua vinculação ao romantismo, Frei Luís de Sousa parece apresentar algumas características que fazem com que ele escape de certo modo ao padrão dos dramas mais típicos da escola romântica. A crítica tradicionalmente tem insistido no fato de o texto de Garrett incorporar certos elementos da tragédia clássica, que seriam em grande parte responsáveis pelo seu tom diferencial e pelo equilíbrio de forma e conteúdo sempre aplaudidos. ${ }^{2}$

Gostaria de conferir neste pequeno ensaio em que medida isso de fato se verifica. Para tanto, pretendo fazer, num primeiro momento, uma síntese comentada da obra, pontuada aqui e ali por algumas formulações de caráter interpretativo. Em seguida, recupero a avaliação que o próprio Garrett fez do seu drama, na época em que foi redigido e representado, no sentido de filiá-lo ao gênero trágico, certamente a principal matriz dos juízos cristalizados pelos estudiosos da literatura subseqüentes. E finalmente, tendo como parâmetro alguns conceitos contidos na Poética de Aristotéles sobre o trágico e passagens de estudiosos do Frei Luís de Sousa que o enquadram no gênero, gostaria de esboçar alguns comentários sobre o texto de Garrett e verificar em que proporção esse enfoque se sustenta.

Frei Luís de Sousa é obra dramática escrita em prosa sobre um argumento de fundo histórico. Suas personagens são construídas a partir de personagens e fatos de finais do séc. XVI e inícios de XVII, quando Portugal, depois do desastre de Alcácer Quibir e problemas sucessórios internos, encontrava-se sob domínio filipino. Toda a ação se passa na vila de Almada, perto de Lisboa, ao longo de alguns poucos dias.

O primeiro ato tem como palco a casa que na vila de Almada possuem D. Manuel de Sousa Coutinho e D. Madalena de Vilhena. Tudo o que aí sucederá estende-se por um tempo concentrado que vai do final da tarde às primeiras horas da noite. Os dois esposos estão por esses dias ali abrigados, juntamente com a filha D. Maria e o aio Telmo Pais, em função da peste que grassa em Lisboa. Ficamos sabendo ainda que existem sérias diferenças entre D. Manuel e os governadores que administram o reino em nome de Filipe II, de Espanha, e que isso vem somar-se ao motivo inicial do afastamento de Lisboa.

Na primeira cena, encontramos D. Madalena solitária a ler em voz alta alguns versos de Luís de Camões, justamente aqueles célebres do episódio de

2 Cf. mais adiante indicação de textos e autores. 
Inês de Castro, do canto III de Os Lusíadas: "Naquele engano d'alma ledo e cego / Que a fortuna não deixa durar muito..." ${ }^{3} \mathrm{D}$. Madalena medita sobre estes versos, e é como um prenúncio dos sucessos posteriores que nós os vamos ler também. Estabelece-se de imediato um paralelo entre a situação de Inês e a de Madalena: a felicidade amorosa e familiar inicial vai ser abruptamente interrompida, cedendo ao desenlace terrível.

Aonde se encontra D. Madalena, vem chegar então Telmo Pais, o aio da família, na cena seguinte. $O$ extenso diálogo que os dois irão travar entre si sintetiza eventos anteriormente ocorridos, fundamentais para a compreensão da situação presente e do que irá se passar a seguir.

Ficamos sabendo que D. Madalena casara em primeiras núpcias com D. João de Portugal, a quem sempre tivera "respeito, devoção, lealdade", mas a quem nunca pudera dedicar o amor que reservava agora ao segundo marido, D. Manuel de Sousa. D. João de Portugal havia desaparecido junto com D. Sebastião e a flor da nobreza militar portuguesa em Alcácer Quibir, em 1578. Depois de sete anos de incessantes buscas, fora dado por morto pela esposa, familiares e conhecidos, excetuando-se Telmo Pais, que o havia criado como a um filho e permanecia fiel à idéia de que ele ainda vivia. Aos dezessete anos, "viúva, órfã e sem ninguém", Madalena resolvera casar novamente, e do novo casamento viera-lhe a filha Maria.

Passavam-se então vinte e um anos desde o desaparecimento de $D$. João de Portugal. Maria tinha treze anos e aos olhos dos pais e de Telmo, que a cla reservava um amor e uma dedicação ainda maiores do que dispensara a $D$. João noutros tempos, era já uma moça crescida e com um amadurecimento pouco comum para a idade. Por diversas vezes será sublinhada a sua perspicácia e a propensão para ler nas coisas sinais e prenúncios não perceptíveis pelo comum das pessoas: "Oh, que eu leio nos olhos, leio, leio!... e nas estrelas do céu também, e sei coisas...". Ou ainda, mais adiante: “... não quero sonhar, que me faz ver coisas... lindas às vezes, mas tão extraordinárias e confusas...". 6 Sua compleição frágil preocupa a todos e a entrada em cena ardendo em febre e excitação parece adiantar desde já o que lhe está reservado para logo mais.

Telmo Pais, que havia servido na casa do primeiro marido de $D$. Madalena e continuava a servir a esta na sua nova situação conjugal, conservava-se, apesar das evidências em contrário, fiel à idéia de que $\mathrm{D}$. João de

3 GARRETT, Almeida. Frei Luís de Sousa. 8. ed. Europa-América, 1995. p. 43.

4 Jbid., p. 50.

5 lbid., p. 48.

6 Jbid., p. 55. 
Portugal não havia morrido em Alcácer Quibir e poderia retornar ainda. Essa esperança viva revelava-se continuadamente o ponto de tensão entre ele e D. Madalena. Telmo guardava na memória as palavras enviadas à esposa em carta pelo antigo senhor na madrugada da fatídica batalha: "Vivo ou morto, Madalena, hei-de ver-vos pelo menos ainda uma vez neste mundo". "É como um presságio, que vai se somando a tantos outros indícios, que cle as lembrava nesse momento.

Telmo Pais, um sebastianista convicto, vai se revelar uma personagem marcada por uma contradição íntima fundamental. Ao mesmo tempo em que é o zelador da memória do antigo senhor, reserva uma dedicação sem limites à $\mathrm{D}$. Maria, a filha do novo casamento. Esta, se aquele ainda vivia como queria crer o aio, era a prova viva da infidelidade de $D$. Madalena e da ilegitimidade da nova ligação conjugal. D. João e D. Maria, os dois objetos do afeto de Telmo, surgiam assim como o passado e o presente postos em confronto.

A jovem D. Maria, que não tem um conhecimento direto dos eventos passados e que portanto ignora os detalhes da sua condição, parece no entanto intuir o que está a suceder. É num diálogo tenso com sua mãe, D. Madalena, que ela, de modo misterioso, e como num presságio, vai dizer: "O que eu sou... só eu o sei, minha mãe... E não sei, não: não sei nada, senão que o que devia ser não sou..."8

Depois de apresentada toda esta situação de partida, o primeiro ato vai terminar com a chegada de D. Manuel, vindo de Lisboa, revoltado com as arbitrariedades dos governadores à serviço de Espanha. A notícia de que, em função da peste, eles haviam resolvido se mudar provisoriamente para Almada, e que a habitação escolhida era justamente a casa de D. Manuel e D. Madalena, é tomada como um afronta pessoal. D. Manuel resolve deixar o lugar como sinal de protesto, e a casa escolhida pelo próprio D. Manuel para que a família seja então abrigada é o antigo paço de $\mathrm{D}$. João de Portugal, que ali vivera com D. Madalena. Ao saber da notícia, Madalena não pode deixar de declarar ao marido, num pressentimento que vem somar-se a tantos já semeados:

MADALENA - Mas é que tu nāo sabes... Eu não sou melindrosa nem de invenções; em tudo o mais sou mulher, e muito mulher, querido; nisso não... Mas tu não sabes a violência, o constrangimento de alma, o terror com que eu penso em ter de entrar naquela casa. Parece-me que é voltar ao poder dele, que é tirar-me dos teus braços, que o vou encontrar ali... - oh, perdoa,

7 GARRET, op. cit., p. 49-50.

8 Ibid., p. 56. 
perdoa-me, não me sai esta idéia da cabeça... - , que vou achar ali a sombra despeitosa de D. João, que me está ameaçando com uma espada de dois gumes... que a atravessa no meio de nós, entre mim e ti e a nossa filha, que nos vai separar para sempre...Que queres...? Bem sei que é loucura; mas a idéia de tornar a morar ali, de viver ali contigo e com Maria, não posso com ela. Sei decerto que vou ser infeliz, que vou morrer naquela casa funesta, que nāo estou ali três dias, três horas, sem que todas as calamidades do mundo venham sobre nós. Meu esposo, Manuel, marido da minha alma, pelo nosso amor to peço, pela nossa filha... Vamos seja para onde for, para a cabana de algum pobre pescador desses contornos, mas para ali, não, oh, não! ${ }^{9}$

Esperados somente para o dia seguinte, anuncia-se então a chegada dos governadores naquele momento, o que vem precipitar os acontecimentos. D. Manuel, numa atitude de desafio, encarnando aqui o patriotismo heróico português, ateia fogo à própria casa como um exemplo de indignação contra a opressão estrangeira. $\mathrm{O}$ seu retrato, que orna uma das paredes, assinalado já desde o início do drama, não escapa ao incêndio, a despeito do esforço de $D$. Madalena em salvá-lo das chamas. A cena acaba por simbolizar a própria ruína da estrutura familiar, como se verificará a seguir.

O segundo ato vai se passar na antiga residência de D. João de Portugal em Almada. No salão principal, três retratos estão nas paredes: os de D. Sebastião, de Camões e do próprio D. João. Passaram-se oito dias desde os acontecimentos anteriores. D. Manuel encontra-se refugiado, vindo à casa somente pela noite e em sigilo.

No início deste segundo ato, Telmo Pais e D. Maria conversam. Diante da interpelação de Telmo, que lhe chama "menina", Maria aproveita para emendar, citando o início do famoso livro de Bernardim Ribeiro: "Menina e moça me levaram da casa de meu pai." 10 Como o fragmento de Camões recitado em voz alta no início do primeiro ato por D. Madalena, esta menção à Menina $e$ moça vai encher-se de significados. É agora o destino de Maria que se concentra resumido nestas mesmas palavras.

Telmo e D. Maria conversam a seguir sobre os retratos na parede. É com reverência que Telmo vai descrevendo à moça cada uma das figuras representadas, a começar por D. Sebastião, o jovem rei desaparecido em Alcácer

9 GARRETT, op. cit., p. 63.

10 Id. 
Quibir, cujo regresso é esperado no íntimo por Telmo; passando a seguir a Camões, que Telmo teria acompanhado na África e na Ásia e cujo triste final de vida testemunhara; até chegar ao terceiro retrato, todo ele envolvido em mistério. A identidade deste último vai sendo aos poucos revelada à moça por Telmo, através de meias palavras. Maria relata o efeito produzido pelo retrato sobre sua mãe assim que chegaram e conclui: "Mas este retrato que ela não nomeia nunca de quem é, e só diz assim às vezes: “O outro, o outro...", este retrato e o de meu pai que se queimou são duas imagens que lhe não saem do pensamento." ${ }^{11} \mathrm{~A}$ identidade do retrato vai ser por fim explicitada pelo próprio $D$. Manuel, que chega ao palácio naquele momento.

Ficamos sabendo a seguir, através de Frei Jorge Coutinho, irmão de D. Manuel, que já não há motivos para que este se esconda. $\mathrm{O}$ arcebispo de Lisboa havia intervido em favor de D. Manuel e os governadores relevaram a afronta. Era preciso agora agradecer ao arcebispo e uma ida a Lisboa se fazia necessária. D. Manuel quer aproveitar a ocasião para visitar D. Joana de Castro, parenta sua que se separara do marido para se dedicar à religião. Novo indício do que sucederá ao final da trama surge aqui indicado. Partem todos, deixando no palácio apenas D. Madalena e Frei Jorge.

É neste passo que algumas revelações mais serão feitas. O dia que corre é sexta-feira da Paixão. D. Madalena, no longo diálogo que travará com Frei Jorge, cheia de receios pela partida do esposo e da filha, fará questão de sublinhar a importância do dia, para explicitar logo a seguir aquele que julga ser o seu grande erro, o pecado que ainda terá de expiar:

MADALENA - Hoje... hoje! Pois hoje é o dia da minha vida que mais tenho receado... que ainda temo que não acabe sem muito grande desgraça... É um dia fatal para mim: faz hoje anos que... que casei a primeira vez, faz anos que se perdeu el-rei $D$. Sebastião e faz anos também que... vi pela primeira vez a Manuel de Sousa.

JORGE - Pois contais essa entre as infelicidades da vossa vida?

MADALENA - Conto. Este amor, que hoje está santificado e bendito no Céu, porque Manuel de Sousa é meu marido, 
começou com um crime, porque eu amei-o assim que o vi... e quando o vi, hoje, hoje... foi em tal dia como hoje! D. João de Portugal ainda era vivo. $O$ pecado estava-me no coração; a boca não o disse... os olhos não sei o que fizeram, mas dentro da alma eu já tinha outra imagem senão a do amante... já não guardava a meu marido, a meu bom... a meu generoso marido... senão a grosseira fidelidade que uma mulher bem nascida quase que mais deve a si do que ao esposo. Permitiu Deus... quem sabe se para me tentar?... que naquela funesta batalha de Alcácer, entre tantos, ficasse também D. João... 12

Imediatamente após esta fala, é anunciada a chegada de um velho romeiro, com desejo de falar à D. Madalena. De barbas muito alvas, sua figura é solene e circunspecta. $O$ diálogo que se trava entre ele, D. Madalena e Frei Jorge vai semeando aos poucos os indícios do posterior reconhecimento:

JORGE - Sois português?

ROMEIRO - Como os melhores, espero em Deus.

JORGE - E vindes?...

ROMEIRO - Do Santo Sepulcro de Jesus Cristo.

JORGE - E visitastes todos os Santos Lugares?

ROMEIRO - Não os visitei; morei lá vinte anos cumpridos.

(...)

JORGE - Pois bem; Deus quis trazer-vos à terra de vossos pais; e quando for sua vontade ireis morrer sossegado nos braços de vossos filhos.

ROMEIRO - Eu não tenho filhos, padre.

JORGE - No seio de vossa familia...

ROMEIRO - A minha família... Já não tenho família.

MADALENA - Sempre há parentes, amigos...

ROMEIRO - Parentes!... Os mais chegados, os que eu me importava achar... contaram com a minha morte, fizeram a sua felicidade com ela; hão-de jurar que me não conhecem.

MADALENA - Haverá tão má gente... e tão vil que tal faça? ROMEIRO - Necessidade pode muito. Deus lho perdoará, se puder! ${ }^{13}$

12 GARRETT, op. cit., p. 84-85.

13 Ibid., p. 87-88. 
O diálogo vai seguindo nesse ritmo de crescente tensão. O Romeiro anuncia então estar vindo da parte de alguém que ficara em Jerusalém e que lhe havia pedido para passar um importante recado à $\mathrm{D}$. Madalena. Instado a transmitir as tais palavras desse outro, o Romeiro vai proferir, incisivo, o que aquele the havia pedido: "Ide a D. Madalena de Vilhena e dizei-lhe que um homem que muito bem the quis... aqui está vivo... por seu mal... e daqui não pôde sair nem mandar-lhe novas suas, de há vinte anos que o trouxeram cativo." 14

As outras informações que vai dando a Frei Jorge e D. Madalena acerca daquele que ficara em Jerusalém vão aos poucos se encaixando, sugerindo a identidade do primeiro marido. Convidado por Frei Jorge a reconhecer entre os três quadros pendurados na parece qual deles correspondia àquele homem que o enviara, o Romeiro aponta, sem nem sequer olhar para a parede, o retrato de D. Manuel. Desesperada, Madalena deixa o recinto gritando pela filha.

E no final do segundo ato, numa cena em que estão sozinhos Frei Jorge e o Romeiro, o reconhecimento enfim se consuma:

JORGE - Romeiro, romeiro, quem és tu?

ROMEIRO (apontando com o bordão para o retrato de D. João de Portugal) - Ninguém!

(Frei Jorge cai prostrado no chão, com os braços estendidos diante da tribuna. $O$ pano desce lentamente.)

O terceiro e último ato acontece também no palácio de $\mathrm{D}$. João de Portugal, em Almada, mas agora o salão principal decorado com os três retratos de D. Sebastião, Camões e D. João cede espaço à parte baixa do palácio, completamente despojada de adornos, que comunica com a capela da Senhora da Piedade, da Igreja de S. Paulo dos frades dominicanos, que se encontra anexa ao palácio. A noite correu, são cerca já de cinco horas. Ali, Frei Jorge e D. Manuel conversam. Além do arcebispo, são os únicos que sabem da verdadeira identidade do Romeiro. 
Da mesma forma que D. Madalena já o fizera à sua maneira no ato anterior, quando ainda não sabia que o antigo esposo ainda vivia mas já sentia os prenúncios de que algo tremendo estava por acontecer, agora é a vez de D. Manuel se penitenciar daquilo que julga ser o seu "erro". Teme pela resolução tomada, pela revelação da identidade do Romeiro e do que isso tudo irá causar à sua filha:

\begin{abstract}
MANUEL - Oh, minha filha, minha filha! (Silêncio longo.) Desgraçada filha, que ficas órfā!... órfã de pai e de mãe... (pausa) e de familia, e de nome, que tudo perdeste hoje... (Levanta-se com violenta aflição.) A desgraçada nunca os teve. Oh, Jorge, que esta lembrança é que me mata, que me desespera! (Apertando a mão do irmão, que se levantou após dele e o está consolando do gesto.) É o castigo terrivel do meu erro... se foi erro... crime sei que não foi. E sabe-o Deus, Jorge, e castigou-me assim, meu irmão! ${ }^{15}$
\end{abstract}

D. Manuel culpa-se por ter desposado D. Madalena. Culpa-se também por ter gerado D. Maria, a principal vítima agora de tudo o que está a suceder. Mas ao mesmo tempo em que reconhece haver um "erro", tem dificuldade em assumir-se plenamente como sujeito desse erro: "É o castigo terrivel do meu erro... se foi erro... crime sei que não foi."

Há ainda um encontro tenso antes do desfecho, entre D. João de Portugal e Telmo Pais, por desejo daquele. Ao saber da identidade do antigo amo, Telmo vai se deixar mergulhar numa grande contradição interior. Ao mesmo tempo em que fora responsável pela manutenção da memória de D. João, julgando-o ainda vivo apesar de tudo, projetando sobre ele o seu sebastianismo esperançoso, Telmo acabara por criar um elo fortíssimo com D. Maria, a quem queria agora como a uma filha e acima do afeto de todos. O regresso de fato de D. João põe imediatamente em risco a posição e mesmo a existência da frágil moça, que todos acreditam não poder resistir a uma tal revelação. É assim que Telmo começa a ter desejado a morte do antigo senhor e isso vai se explicitar a D. João. É numa fala também carregada de emoção que a culpa vivida pelos outros protagonistas vai atravessar a consciência deste, que num último gesto procura ainda reverter os acontecimentos: 
ROMEIRO - Eu... Vai, saberás de mim quando for tempo. Agora é preciso remediar o mal feito. Fui imprudente, fui injusto, fui duro e cruel. E para quê? D. João de Portugal morreu no dia em que sua mulher disse que ele morrera. Sua mulher honrada e virtuosa, sua mulher que ele amava... - oh, Telmo, Telmo, com que amor a amava eu! - sua mulher que ele já não pode amar sem desonra e vergonha!... Na hora em que ela acreditou na minha morte, nessa hora morri. Com a mão que deu a outro riscou-me do número dos vivos. D. João de Portugal não há-de desonrar a sua viúva. Não, vai; dito por ti terá dobrada força: dize-lhe que falaste com o Romeiro, que o examinaste, que o convenceste de falso e de impostor... dize o que quiseres, mas salva-a a ela da vergonha e ao meu nome da afronta; a memória dele que fique sem mancha. Está em tuas mãos, Telmo; entregote mais que a minha vida. Queres faltar-me agora? ${ }^{16}$

E chegamos então às últimas cenas. $O$ desejo de $D$. João já não pode se realizar. Estamos dentro da igreja de S. Paulo, na presença do arcebispo e de um coro de frades dominicanos, que rezam em latim, e a oração vai pontuar e comentar, como nos antigos coros gregos, a fala das personagens. É o momento em que se vai realizar a ordenação de D. Madalena e D. Manuel, a partir de agora Frei Luís de Sousa. A separação, acompanhada do ingresso na vida religiosa por parte de ambos, se afigurou como única saída possível para toda a situação.

No entanto, Maria, "em estado de completa alienação" 17 , cuja saúde havia piorado muito, vai adentrar o recinto justamente no instante em que a cerimônia se inicia. Contempla atônita o que se passa e, mesmo que tudo lhe tenha sido ocultado até então, adivinha o que está a suceder. Ouve a voz do Romeiro ao fundo, que tenta ainda incitar Telmo a interferir nos acontecimentos, e é no clímax do patético que o drama vai chegar ao seu termo:

MARIA (apontando para o Romeiro) - É aquela voz, é ele, é ele! Jả não é tempo... Minha mãe, meu pai, cobri-me bem estas faces, que morro de vergonha... (Esconde o rosto no seio da mãe.) Morro, morro... de vergonha.

16 GARRETT, op. cit., p. 106.

17 Ibid., p. 112. 
(Cai e fica morta no chão. Manuel de Sousa e Madalena prostram-se ao pé do cadáver da filha.)

MANUEL (depois de algum espaço, levanta-se de joelhos) Minha irmã, rezemos por alma... encomendemos a nossa alma a este anjo, que Deus levou para si. Padre Prior, podeis-me lançar aqui o escapulário?

O PRIOR (indo buscar os escapulários ao altar-mor e tomando) - Meus irmãos, Deus aflige neste mundo àqueles que ama. A coroa de glória não se dá senão no Céu.

(Toca o órgão; cai o pano.) ${ }^{18}$

A primeira pessoa a salientar o fato de que o Frei Luís de Sousa escapa aos limites do drama tipicamente romântico por incorporar elementos oriundos da tragédia clássica é o próprio Almeida Garrett. E ele o fará justamente por ocasião da leitura do seu drama durante sessão do Conservatório Real de Lisboa, ocorrida em 6 de maio de 1843. Na memória "Ao Conservatório Real", que acompanha o texto e que foi ali conjuntamente apresentada, essa será a tônica da avaliação que o autor fará da sua própria obra.

Desde os primeiros parágrafos de "Ao Conservatório Real", Garrett vai procurar chamar a atenção nesse sentido. Ao referir-se à história portuguesa como possível fonte para a elaboração literária, é nestes termos que ele o faz:

É singular condição dos mais belos factos e dos mais belos caracteres que ornam os fastos portugueses serem tantos deles, quase todos eles, de uma extrema e estreme simplicidade. As figuras, os grupos, as situações da nossa história - ou da nossa tradição, que para aqui tanto vale - parecem mais talhados para se moldarem e vazarem na solenidade severa e quase estatuária da tragédia antiga do que para se pintarem nos quadros - mais animados talvez, porém menos profundamente impressivos, do

18 GARRETT, op. cit., p. 114. 
drama novo - ou para se entrelaçarem nos arabescos do moderno romance. 19

Como salienta Garrett, é já na própria matéria-prima da história portuguesa que se reconhecem alguns aspectos que a vinculam preferencialmente ao trágico. A simplicidade desta quadra melhor com a solenidade da tragédia antiga do que com a animação do drama e as complicações do romance moderno. $\mathrm{O}$ autor sugere que há nestes algo de excessivo, superficial e ornamental que, segundo ele, não vai bem com o despojamento severo das ações e dos caracteres do passado luso.

E do meio da história portuguesa, um episódio como o que é extraído por Garrett é mais do que digno de ombrear com a matéria dos grandes trágicos gregos:

$\mathrm{Na}$ história de Frei Luís de Sousa, como a tradição a legou à poesia, e desprezados para este efeito os embargos da crítica moderna - a qual, ainda assim, tão-somente alegou mas não provou -, nessa história, digo, há toda a simplicidade de uma fábula trágica antiga. Casta e severa como as de Ésquilo, apaixonada como as de Eurípedes, enérgica e natural como as de Sófocles, tem de mais do que essoutras aquela unção e delicada sensibilidade que o espírito do cristianismo derrama por toda ela, molhando de lágrimas contritas o que seriam desesperadas ânsias num pagão, acendendo até nas últimas trevas da morte a vela da esperança, que se não apaga com a vida. ${ }^{20}$

O elemento cristão, segundo Garrett, não entra de modo algum em contradição com o trágico antigo. Pelo contrário, na sua avaliação, há algo nele que vem ainda refinar o sentido do trágico, como fica claramente indicado acima e como se evidencia logo a seguir na consideração que Garrett faz do elemento catastrófico no Frei Luís de Sousa:

A catástrofe é um duplo e tremendo suicídio, mas não se obra pelo punhal ou pelo veneno: foram duas mortalhas que caíram

19 GARRETT, op. cit., p. 121.

20 Id. 
sobre dois cadáveres vivos; jazem em paz no mosteiro, o sino dobra por eles: morreram para o mundo, mas vão esperar ao pé da Cruz que Deus os chame quando for a sua hora. ${ }^{21}$

E para confirmar sua argumentação, Garrett compara ainda o destino dos heróis que habitam o seu drama ao de conhecidas personagens das tragédias gregas, sempre no sentido de evidenciar que aquelas de modo algum devem algo a estas:

A desesperada resignação de Prometeu, cravado de cravos no Cáucaso, rodeado de curiosidade e compaixōes, e com o abutre a espicaçar-lhe no fígado, não é mais sublime. Os remorsos de Édipo não são para comparar aos esquisitos tormentos de coração e espírito que aqui padece o cavalheiro pundonoroso, $o$ amante delicado, o pai estremecido, o cristão sincero e temente do seu Deus. Os terrores de Jocasta fazem arrepiar carnes, mas são mais asquerosos do que sublimes; a dor, a vergonha, os sustos de D. Madalena de Vilhena revolvem mais profundamente no coração todas as piedades, sem o paralisar de repente com uma compressão de horror que excede as forças do sentimento humano. $^{22}$

Mas se a matéria-prima de que se nutre é essencialmente trágica, Garrett tem algum pudor em chamar "tragédia" ao seu drama:

Esta é uma verdadeira tragédia - se as pode haver, e como só imagino que as possa haver, sobre factos e pessoas comparativamente recentes. Não the dei, todavia, esse nome porque não quis romper de viseira com os estafermos respeitados dos séculos que, formados de peças que nem ofendem nem defendem no actual guerrear, inanimados, ocos e postos ao canto da sala para onde ninguém vai de propósito, ainda têm, contudo, a nossa veneração, ainda nos inclinamos diante deles quando ali passamos por acaso. ${ }^{23}$

21 GARRET, op. cit., p. 121.

22 lbid., p. 121-122.

23 Ibid., p. 122. 
Esse pudor, manifestado no fragmento acima em parte como reverência aos antigos, deve-se ainda ao fato de o meio linguiistico através do qual o texto se encontra vazado não ser o verso e sim a prosa:

Demais, posto que eu não creia no verso como língua dramática possível para assuntos tão modernos, também não sou tão desabusado, contudo, que me atreva a dar a uma composição em prosa o título solene que as musas gregas deixaram consagrado à mais sublime e difícil de todas as composições poéticas. ${ }^{24}$

Assim, é de modo algo contraditório que ele vai concluir esta tentativa de classificação da sua obra:

Contento-me para a minha obra com o título modesto de drama; só peço que a não julguem pelas leis que regem, ou devem reger, essa composição de forma e índole nova; porque a minha, se na forma desmerece da categoria, pela índole há de ficar pertencendo sempre ao antigo género trágico. ${ }^{25}$

Garrett faz uma cisão clara entre forma e conteúdo. Pela forma, entendida aqui em termos da opção entre verso e prosa, Frei Luís de Sousa se enquadra na categoria do "drama moderno". Pelo conteúdo, ou pela "índole", como prefere chamar Garrett, seu texto é trágico. E isto se propõe como problema meio insolúvel para a crítica sua contemporânea, que deve reconhecê-lo como um "drama" sem estar autorizada a julgá-lo dentro das regras que regem o novo gênero.

Ainda numa passagem mais adiante, o problema da "índole" trágica do seu texto retorna, agora numa consideração um pouco mais detalhada das suas ações e dos seus caracteres, bem como da explicitação da sua finalidade:

Nem amores, nem aventuras, nem paixões, nem caracteres violentos de nenhum gênero. Com uma ação que se passa entre pai, mãe e filha, um frade, um escudeiro velho e um peregrino que

24 GARRET, op. cit., p. 122.

25 Id. 
apenas entra em duas ou três cenas - tudo gente honesta e temente a Deus -, sem um mau para contraste, sem um tirano que se mate ou mate alguém, pelo menos no último acto, com eram as tragédias dantes - sem uma dança macabra de assassínios, de adultérios e de incestos, tripudiada ao som das blasfémias e das maldições, como hoje se quer fazer o drama -, eu quis ver se era possivel excitar fortemente o terror e a piedade ao cadáver das nossas platéias, gastas e caquécticas pelo uso contínuo de estimulantes violentos, galvanizá-lo com sós estes dois metais de lei. ${ }^{26}$

Garrett volta a insistir no despojamento das ações e das personagens. $\mathrm{E}$ aqui, de forma bem explícita, lê-se, pelo contraste, a condenação dos excessos do drama romântico, que por meio de "estimulantes violentos" vai anestesiando a sensibilidade do público. Sem a presença de um "mau" claramente discernivel como motor das ações e reações, contando com personagens que não cometem voluntariamente atos nefastos, e que portanto não podem ser julgadas por parâmetros morais de correção e incorreção, justiça e injustiça, mas que sucumbem a um destino que paira acima delas, $o$ autor reconhece ter diante de si uma ação trágica por excelência. E é por isso que percebe possível "excitar fortemente o terror e a piedade" sobre o seu público, como postulava como finalidade da tragédia o próprio Aristóteles.

Antes de Frei Luís de Sousa, sua obra-prima no teatro, Almeida Garrett visitou seguidamente o gênero. São ainda do seu período acadêmico (terminou o curso jurídico na Universidade de Coimbra em 1821) as tragédias Lucrécia, Xerxes, Mérope, Atala, Afonso Africano, Sofonisba e Édipo, exercícios juvenis de quem está a se instruir na cultura clássica. Em 1821 publica e faz representar o seu Catão, também dentro dos moldes classicizantes das obras anteriores.

Quando os influxos do romantismo se fazem incidir sobre sua formação, aborda matéria histórica dentro dos moldes do drama romântico, como em Um auto de Gil Vicente (representado em 1838 e publicado em 1842), D. Filipa de Vilhena (representado em 1840 e publicado em 1846) e O alfageme de Santarém (representado e publicado em 1842). Revela-se aqui, como em toda a sua obra. um autor de transição entre escolas, e essa ambidestria não poderá deixar de contaminar o seu drama mais maduro: o Frei Luís de Sousa. ${ }^{27}$

26 GARRETT, op. cit., p. 123.

27 A historiografia literária tradicional recorrentemente insiste nesse debater-se de Garrett entre sua formação arcádica de viés classicizante e o seu contato, já na maturidade, com o romantismo europeu, de que foi introdutor em Portugal. Cf., p.ex., a esse respeito, o que escreveram os seguintes autores: SARAIVA; LOPES (História da literatura portuguesa, p. 744-745), MOISÉS 
Gostaria de tentar agora uma aproximação entre alguns dos conceitos desenvolvidos por Aristóteles em sua Poética e o drama Frei Luís de Sousa, de Almeida Garrett, no sentido de avaliar em que medida ele pode, como quer seu próprio autor e como insinuam tradicionalmente muitos dos historiadores da Literatura Portuguesa, ser vinculado ao gênero trágico.

Aristóteles, na Poética, define a tragédia do seguinte modo: "É pois a tragédia imitação de uma ação de caráter elevado, completa e de certa extensão, em linguagem ornamentada e com as várias espécies de ornamentos distribuídas pelas diversas partes [do drama], [imitação que se efetua] não por narrativa, mas mediante atores, e que, suscitando o 'terror e a piedade, tem por efeito a purificação dessas emoções", 28

Segundo Aristóteles, "poesia" é "imitação", e os diferentes gêneros poéticos (bem como as diferentes linguagens artísticas) distinguem-se entre si em função dos "objetos", do "modo" e do "meio" que dizem respeito à imitação, além da "finalidade" a que servem. Assim, tomando a definição de tragédia acima transcrita, o objeto imitado pela tragédia seria "uma ação de caráter elevado, completa e de certa extensão"; o meio de imitação seria a "linguagem ornamentada"; o modo pelo qual ela se efetua não seria a "narrativa", mas "mediante atores"; e sua finalidade, a de suscitar "o terror e a piedade" para a "purificação dessas emoções".

Com relação ao "meio", no caso da tragédia a "linguagem ornamentada", Aristóteles complementa ainda: "Digo ornamentada a linguagem que tem ritmo, harmonia e canto, e o servir-se separadamente de cada uma das espécies de ornamentos significa que algumas partes da tragédia adotam só o verso, outras também o canto". 29

O próprio Garret já se mostrava atento ao fato de que um dos aspectos que fragilizavam o enquadramento de Frei Luís de Sousa no gênero trágico dizia respeito à sua opção pela prosa e não pelo verso: "também não sou tão desabusado (...) que me atreva a dar a uma composição em prosa o título solene que as musas gregas deixaram consagrado à mais sublime e difícil de todas as composições poéticas". As tragédias do classicismo europeu já haviam deixado

(A literatura portugutesa, p. 134, ou ainda Presença da literatura portuguesa, v. 3, p. 26), FIGUEIREDO (História literária de Portugal, p. 319) e SIMÕES (Garrett: vida, pensamento, obra. p. 104 et seq.).

28 ARISTÓTELES. Poética. Tradução, prefácio, introdução, comentários e apêndices de Eudoro de Souza. 1. ed. Coleção Os Pensadores. São Paulo: Abril Cultural, 1972. p. 447.

29 ARISTÓTELES, op. cit., p. 447-448. 
de lado o componente musical presente nos modelos gregos ${ }^{30}$, mas faziam ainda do verso (a linguagem com "ritmo") um elemento fundamental de composição. Para Garrett, como para tantos outros dramaturgos a partir do séc. XIX, o verso não parecia mais adequado como meio de expressão para o gênero dramático. É assim que ele insiste que o trágico, no seu caso, não poderia ser encontrado aí nesse nível, mas se vincularia muito mais à "matéria" e à "índole" da sua obra, como mais acima já ficou referido.

É certamente com relação ao "objeto" imitado ("uma ação de caráter elevado, completa e de certa extensão") que poderemos encontrar mais afinidades entre o texto de Garrett e algumas das características que compõem o gênero trágico.

Ao definir os "objetos" que podem ser imitados pela poesia, Aristóteles diz o seguinte:

Mas, como os imitadores imitam homens que praticam alguma ação, e estes, necessariamente, são indivíduos de elevada ou de baixa índole (porque a variedade dos caracteres só se encontra nestas diferenças [e, quanto a caráter, todos os homens se distinguem pelo vício e pela virtude]), necessariamente também sucederá que os poetas imitam homens melhores, piores ou iguais a nós, como o fazem os pintores (...).

Pois a mesma diferença separa a tragédia da comédia; procura, esta, imitar os homens piores, e aquela, melhores do que eles ordinariamente são. ${ }^{31}$

De fato, todas as ações presentes em Frei Luis de Sousa dizem respeito a caracteres elevados. Daí a ausência do elemento cômico, do riso, que se vincula à representação de ações e caracteres inferiores. Nada aqui vai ecoar o ridículo e o grotesco característicos de muitos dramas românticos, essencial para a fusão do "trágico" e do "cômico" cara a estes. Todas as personagens são exemplos de elevação moral. Todas, excetuando-se Telmo Pais, que escapa à sua condição social pela "nobreza" das atitudes, são ainda de extração aristocrática. Nenhuma

30 Não se pode, no entanto, deixar de se pensar na ópera, consolidada a partir do séc. XVII, como composição artística para onde migraram a poesia e a música das antigas tragédias gregas.

31 ARISTÓTELES, op. cit., p. 444. 
delas concentra sobre si "ações más", como acontece no universo mais tipicamente romântico, maniqueísta por excelência na oposição que faz entre "bem" e "mal". Se as personagens passam da dita para a desdita, isso não se dá em função de más ações, mas sim em função do erro trágico, que diz menos respeito aos caracteres do que à estruturação da ação em si.

Com relação à ação, à composição da fábula, Aristóteles é claro quanto à necessidade de o poeta procurar a coerência interna, a unidade e completude:

Por conseguinte, tal como é necessário que nas demais artes miméticas una seja a imitação, quando o seja de um objeto uno, assim também o mito, porque é imitação de ações, deve imitar as que sejam unas e completas, e todos os acontecimentos se devem suceder em conexão tal que, uma vez suprimido ou deslocado um deles, também se confunda ou mude a ordem do todo. Pois não faz parte de um todo o que, quer seja quer não seja, não altera esse todo. ${ }^{32}$

Essa exigência de unidade dramática desdobrou-se posteriormente, nas teorizações que tomaram a Poética como referencial teórico, na chamada "lei das três unidades": unidades de ação, tempo e espaço. Certamente Frei Luís de Sousa aproxima-se dessa exigência da poética clássica. Nele não temos nem a multiplicação de episódios e quadros com certo grau de independência, como era comum nos autos medievais ou no teatro popular, por exemplo, nem tampouco uma ampliação muito grande dos limites espacias ou temporais da matéria representada, como é comum no drama romântico. A esse respeito, pode-se citar ainda comentário de J. Tomaz Ferreira:

A tragédia clássica exigia as chamadas "três unidades", de tempo, de espaço e de aç̧ão. Ora, no Frei Luís de Sousa, o tempo e o espaço só se diversificam na exacta medida que é exigida pela verossimilhança da acção. Entre o primeiro e o segundo actos medeiam oito dias, e escassas horas separam a acção do segundo e do terceiro actos. Tudo se passa em Almada, e a própria mudança de cenários intervém, se assim se pode dizer, na acção, pois pesa decisivamente no ânimo de $\mathrm{D}$. Madalena de Vilhena para lhe acentuar o clima de agouros e presságios que 
se adensa a preparar o desenlace temido.

Tudo isto é possível porque a aç̧ão é colhida muito perto já do desenlace, como mandavam as regras, e é ao longo dela que vamos tomando conhecimento dos pressupostos que fazem duma situação em si perfeitamente normal uma caixa incubadora da tragédia em que se resolverá a acção. ${ }^{33}$

Ainda com relação à ação, o tex to de Almeida Garrett parece enquadrarse bastante bem nos moldes das tragédias com fábula complexa, aquelas "em que a mudança se faz pelo reconhecimento ou pela peripécia, ou por ambos conjuntamente". Na definição de Aristóteles, “"peripécia' é a mutação dos sucessos no contrário (...); e esta inversão deve produzir-se (...) verossímil e necessariamente". Por sua vez, "o 'reconhecimento, como indica o próprio significado da palavra, é a passagem do ignorar ao conhecer, que se faz para amizade ou inimizade das personagens que estão destinadas para a dita ou para a desdita". 34

Frei Luís de Sousa tem peripécia e reconhecimento. Com a chegada do Romeiro e a notícia de que $\mathrm{D}$. João de Portugal ainda vive dá-se a reviravolta da ação. A situação de relativa felicidade em que se encontrava a família é posta $\mathrm{em}$ xeque. Todas as relações serão estremecidas. A ligação conjugal entre D. Madalena e D. Manuel, legítima até antes da revelação, transforma-se numa relação potencialmente adulterina. A filha do casamento dos dois, D. Maria, passa de filha legítima para ilegítima. Telmo Pais, zelador da memória do antigo amo, vê-se subitamente na condição de traidor dessa memória, e, por conseguinte, traidor do próprio D. João. A peripécia é acompanhada ainda de reconhecimento, formidavelmente articulado por Garrett na cena em que o Romeiro revela a Frei Jorge a sua identidade.

Assim, unindo peripécia e reconhecimento, a obra de Garrett acaba por adequar-se a outra exigência aristotélica, àquela por meio da qual se obtém "a mais bela forma de reconhecimento":

A mais bela de todas as formas de reconhecimento é aquela a que se dá juntamente com a peripécia, como, por exemplo, no Édipo. E outras há ainda, pois com seres inanimados e casos

33 FERREIRA, J. Tomaz. Almeida Garrett: o homem e a obra. In: GARRETT, Almeida. Frei Luis de Sousa. 8. ed. Europa-América, 1995. p. 34.

34 ARISTÓTELES, op. cit., p. 454. 
acidentais também pode dar-se o reconhecimento do modo como ficou dito; e também constitui reconhecimento o haver ou não haver praticado uma ação. Mas é a primeira forma aquela que melhor corresponde à essência do mito e da ação, porque o reconhecimento com peripécia suscitará terror e piedade, e nós mostramos que a tragédia é imitação de ações que despertam tais sentimentos. E demais, a boa ou má fortuna resultam naturalmente de tais ações. 35

Além de reconhecimento e peripécia, as tragédias contêm ainda um terceiro elemento, segundo Aristóteles, que diz respeito à catástrofe: "A catástrofe é uma ação perniciosa e dolorosa, como o são as mortes em cena, as dores veementes, os ferimentos e mais casos semelhantes". ${ }^{36}$ A morte em cena de $\mathrm{D}$. Maria no final, no instante em que seus pais se encontram em meio à cerimônia que os há de separar definitivamente, e eles dela, compõe o instante catastrófico do drama de Garrett. Contribui certamente para intensificar os sentimentos de terror e piedade, característicos do trágico. D. Maria morre fisicamente; $\mathrm{D}$. Manuel e $\mathrm{D}$. Madalena morrem para o mundo.

Certamente, não seria de todo forçado reconhecer no texto a existência dos sentimentos de terror e piedade, e da sua consequiente purgação ao final, como indicava Aristóteles ser a finalidade da tragédia e como reconhecia Garrett como presentes no seu texto. A inexorabilidade dos acontecimentos, rigorosamente amarrados, a inexistência de uma culpa facilmente identificável, atribuível às ações das personagens, consistindo o erro (o erro trágico) no modo como o destino se configura diante das personagens, escapando portanto completamente da possibilidade de uma intervenção humana, tudo parece aproximar Frei Luis de Sousa do espírito da tragédia grega, a despeito de todos os elementos "modernos" que também lhe dizem respeito.

Nesse sentido, e agora à guisa de conclusão, mais uma vez o juízo de J. Tomaz Ferreira parece caber bastante bem aqui:

A presidir a todo o desenrolar da acção, a ananké, o destino, ou $o$ fado. $O$ fado rege a vida dos homens e nem os deuses se lhe abstraem. E é bom notar como, neste caso concreto, ele escapa ao próprio contexto cristão em que o drama tem lugar. Castigo de Deus, o aparecimento do Romeiro? Mas nem o Deus dos 
cristãos é um Deus castigador, nem havia falta que merecesse tal castigo. Ressalta com toda a clareza, ao longo da ação, a perfeita boa-fé dos intervenientes. D. João de Portugal não morrera, é verdade, mas tudo se fizera para determinar o seu paradeiro sem resultado. (...) Havia, é certo, aquela inclinação de Madalena para Manuel de Sousa: inclinação inconseqüente, tanto quanto dependia da vontade humana, a que não obedecem, como se sabe, as razões do coração. Mas tanto basta para que o destino desafiado se encarregue da vingança. ${ }^{37}$

Assim, Garrett parece ter conseguido chegar a uma forma híbrida que, ao invés de mera diluição literária ou indecisão entre modelos, retira sua força e permanência justamente desse dualismo. Seu drama histórico, em parte claramente vinculado à escola romântica, bebe também das fontes gregas por meio da formação clássica do seu autor e da natureza da matéria tratada. $\mathrm{O}$ espírito trágico e clássico cerceia os possíveis excessos e maneirismos românticos, dá estatuto de universalidade ao que poderia se perder no particularismo. Por sua vez, a tradição surge atualizada na forma renovada, o que lhe dá interesse de contemporaneidade.

\section{RESUMO}

O presente artigo procura verificar em que medida Frei Luís de Sousa, de Almeida Garrett, um drama histórico romântico, escapa aos limites do gênero ao incorporar elementos da tragédia clássica. Primeiramente são apresentadas algumas formulações do próprio autor que apontam nessa direção. Em seguida, faz-se um estudo da obra à luz de alguns dos conceitos da Poética de Aristóteles.

Palavras-chave: Almeida Garrett, Frei Luís de Souza, drama romântico.

37 FERREIRA, J. Tomaz. Almeida Garret... 


\begin{abstract}
This article tries to verify how Frei Luis de Sousa by Almeida Garrett, a romantic and historic drama, escapes the limits of the genre by incorporating elements of classic tragedy. Initially, the author himself points in that direction. After, a study is done according to some concepts of Aritotle's Poetics.
\end{abstract}

Key-words: Almeida Garrett, Frei Luís de Souza, romantic drama.

\title{
REFERÊNCIAS BIBLIOGRÁFICAS
}

ARISTÓTELES. Poética. Tradução, prefácio, introdução, comentários e apêndices de Eudoro de Souza. 1. ed. Coleção Os Pensadores. São Paulo: Abril Cultural, 1972. FERREIRA, J. Tomaz. Almeida Garrett: o homem e a obra. In: GARRETT, Almeida. Frei Luís de Sousa. 8. ed. Europa-América, 1995.

FIGUEIREDO, Fidelino de. História literária de Portugal. Coimbra: Nobel, 1944.

GARRETT, Almeida. Frei Luís de Sousa. 8. ed. Europa-América, 1995.

MOISÉS. Massaud. A literatura portuguesa. 27. ed. São Paulo: Cultrix, 1994.

MOISÉS, Massaud. (Org.) Pequeno dicionário de literatura portuguesa. São Paulo: Cultrix, 1981.

MOISÉS, Massaud. Presença da literatura portuguesa. In: AMORA, Antônio Soares (Dir.). v. 3 - Romantismo - Realismo. 2. ed. São Paulo: DIFEL, 1967.

SARAIVA, António José; LOPES, Óscar. História da literatura portuguesa. 12. ed. Porto: Porto Editora, 1982.

SIMÕES, João Gaspar. Almeida Garrett: vida, pensamento, obra. Lisboa: Editorial Presença, 1964. 